\title{
Memory as a soft power: A case of Polish-Lithuanian dialogical memory
}

\author{
PRZEMYSŁAW ŁUKASIK \\ PH.D. ASSISTANT PROFESSOR \\ ORCID: 0000-0003-2358-9770 \\ Pedagogical University Cracow, Political Studies Department \\ email: przemyslaw.lukasik@up.krakow.pl
}

Keywords: $\quad$ Polish-Lithuanian relations, politics of memory, dialogical memory, soft power

Abstract By the concept of dialogical memory we understand the process of creating transnational memory in the course of complementing individual national memories. In the opinion of its inventor, the German memoryologist Aleida Assmann, dialogical memory is particularly important for the nations with a difficult past. A responsible and empathic narration of a shared history can lay the foundation for a normal relationships in the future. The purpose of the article is to analyze the phenomenon of dialogical memory as exemplified by the Polish-Lithuanian debate on the common past and its impact on the current political relations. In recent times we can observe the organized anniversary celebrations by the governments of both countries related to the history of the Polish-Lithuanian Commonwealth, a common state that existed between the $16^{\text {th }}$ and $18^{\text {th }}$ centuries. A special historical celebration took place in Vilnius in November 2019. With the participation of the delegations from Poland, Belarus and Ukraine, the remains of the heroes who took part in the anti-Russian January Uprising in 1863-1864 were buried with honours. These celebrations mark a characteristic change that took place in the Lithuanian politics of memory in relation to the assessment of the traditions of the common Polish-Lithuanian state. A community of interests in the sphere of security, economy, and politics is deepening this process. Membership in the European Union and the Atlantic Pact are platforms joining Poles and Lithuanians in the $21^{\text {st }}$ century. This membership provides opportunities for both states to cooperate and develop common interests and values. Common neighbourhood with the Russian exclave in Kaliningrad and a sense of threat from Russia deepens mutual Polish-Lithuanian understanding.

\section{Pamięć jako miękka siła na przykładzie polsko-litewskiej pamięci dialogicznej}

Słowa kluczowe: stosunki polsko-litewskie, polityka pamięci, pamieć dialogiczna, miękka siła

Abstrakt Pod pojęciem pamięci dialogicznej, w toku uzupełniania indywidualnych pamięci narodowych, rozumiemy proces tworzenia się pamięci transnarodowej. Zdaniem twórczyni tego pojęcia, niemieckiej pamięciolog Aleidy Assmann, pamięć dialogiczna jest szczególnie ważna dla narodów z trudną przeszłością. Odpowiedzialna i empatyczna narracja o wspól- 
nej historii może bowiem stanowić podstawę normowania przyszłych relacji. Celem artykułu jest analiza zjawiska pamięci dialogicznej, na przykładzie polsko-litewskiej debaty na temat wspólnej przeszłości i jej wpływu na aktualne stosunki polityczne. W ostatnim czasie możemy obserwować organizowane przez rządy obu krajów obchody rocznicowe związane z historią Rzeczypospolitej Obojga Narodów, wspólnego państwa istniejącego między XVI a XVIII wiekiem. W Wilnie w listopadzie 2019 roku odbyła się specjalna uroczystość historyczna - pochowano z honorami szczątki bohaterów, którzy wzięli udział w antyrosyjskim powstaniu styczniowym w latach 1863-1864. Wzięły w niej udział delegacje z Polski, Białorusi i Ukrainy. Uroczystości te wyznaczają charakterystyczną zmianę, jaka dokonała się w litewskiej polityce pamięci w kwestii oceny wspólnego, państwa polsko-litewskiego, dziedzictwa. Proces ten pogłębia wspólnota interesów w sferze bezpieczeństwa, gospodarki i polityki. Członkostwo w Unii Europejskiej i Sojusz Północnoatlantyckim to platformy łączące Polaków i Litwinów w XXI wieku. Członkostwo to daje obu państwom możliwość współpracy i rozwijania wspólnych interesów i wartości. Wspólne sąsiedztwo z rosyjską eksklawą w Kaliningradzie i poczucie zagrożenia ze strony Rosji pogłębia wzajemne polsko-litewskie zrozumienie.

\section{Text structure, research method, research questions}

The article consists of two parts. In the first part I will present the process of shaping dialogical memory. To this end the relations between history and cultural memory as well as the politics of memory in the scientific discourse will be discussed. The next part is the description of the contemporary Polish-Lithuanian relations. Subject here will be the transformations in the politics of memory of both countries, which are becoming factors in shaping a common dialogical memory.

The scientific methods that I will use are the historical method and the comparative method. Using these methods I refer to the analysis of available data, including: the opinions expressed in the discourse of historians and memoryologists on the relationship between history, memory, and historical policy, the statements and interviews with the Polish and Lithuanian politicians, the changes in historical discourse, the curricula, and the opinions of both nations expressed in the opinion polls.

The main research questions are:

How is historical memory becoming an instrument of the soft power of the state? What is the turn in the Polish-Lithuanian politics of memory in the recent 30 years and what role does the history of the First Polish Republic play in it? What factor is Russia in the Polish-Lithuanian politics of memory? Are these changes an expression of the shaping of the Polish-Lithuanian dialogical memory?

\section{Soft power}

The inventor of the concept of soft power is an American political scientist Joseph Nye. Nye worked in the administration of American presidents Jimmy Carter and Bill Clinton. He was also co-author of the theory of interdependence in international relations, which he developed together with Robert Keohane. In his analysis of international relations, he believed that countries fighting 
for survival and increasing their power should focus on cooperation, not rivalry. This was due to Nye's faith as a neo-liberal in values such as the development of democracy, human freedom and equal opportunities, as well as to the noticeable growing interdependence in international relations (Nye, 2017).

The genesis of the concept of soft power is associated with the search for non-material resources of strength. British historian Paul Kennedy in his book The rise and fall of the great powers: Economic change and military conflict from 1500 to 2000 announced in 1987 the end of the US superpower (Kennedy, 1994). The reason for the fall of the American superpower position, as with other powers in history, was supposed to be the „excessive imperial extension” of US influence. Nye, disputing with the British historian, wrote a book Bound to lead. The changing nature of American power (Nye, 1991), in which he pointed out that in order to maintain the American power, modifications involving the skillful use of ,hard power” and ,soft power” were necessary. Before the American political scientist employed the concept of soft power, other thinkers also tried to address these issues. Pierre Bourdieu wrote about symbolic violence, Max Weber about authority categories, Michel Foucault about a disciplinary device, and Jürgen Habermas about communication.

According to the theory of international relations, countries seek to pursue their strife with other countries that also aspire to increase their power. The strength of the state is an ability to impose its will on others, or at least defend itself against the imposition of will. According to Nye, the hard power of the state is clearly determined by the tangible resources such as population, territory, raw materials, economy, and army. Hard power is the so-called first face of power that allows states to achieve goals through coercion or bribery.

According to Nye, Americans learned about hard power restrictions when the United States lost the Vietnam War. The country, deprived of a long-term strategy and skilful leadership, was doomed to failure. According to the political scientist, after the collapse of the USSR, in the new geopolitical reality Americans should develop a cooperative force, i.e. a soft force expressed in establishing agendas, persuasiveness, and attractiveness (Nye, 2012). Nye referred to the opinions of the $18^{\text {th }}$-century Scottish philosopher David Hume, who believed that no man is strong enough to achieve his goals alone.

The war that the United States began in 2003 with Iraq was to prove that sometimes hard power destroys soft power. That is why in 2004 another book was published that introduced the concept of „smart power” understood as an ability to combine resources of hard and soft power into effective strategies. Nye also made an in-depth analysis of the concept of smart power itself. He emphasized that success in the operation of soft power depends on the attitude of the other party and the level of credibility of the state. The sources of soft power are to lie in the culture, political values, and foreign policy of the state reaching for them.

However, Nye pointed out that the tool of soft power was in the hands of civil society, not the government. What creates positive attractiveness of the society is, among others, the same attitude towards values, e.g. charity, competence, beauty. In a situation of constant information flow, the key issue is the fight for attention and recognition. In this context, Nye wrote about the 
need for: everyday communication, strategic communication, and the role of public diplomacy. The final victory in this competition is to be achieved by those countries which prove to be the most credible. Thus, the narration of the state becomes a currency of soft power, Nye argues (Nye, 2012).

The case of the contemporary Lithuanian-Polish relations shows how the historical narrative of the state can be used as a currency of soft power. In addition to the community of political and economic interests and security (classified as hard power), but with large cultural and linguistic differences (Poles are Central European Slavs, while Lithuanians belong to the Baltic States emphasizing their cultural ties with Scandinavia), their common history becomes an important capital for the future bilateral relations. However, the path leading to Lithuanian-Polish dialogical memory was long and bumpy.

\section{History and memory}

When discussing the impact of the memory of the Polish-Lithuanian Commonwealth on the contemporary Polish-Lithuanian relations, it is necessary to recall issues related to the relationship between memory and history, cultural memory, and politics of memory.

Historical memory is a form of memory referring to the past of a social group (Stobiecki, 2018). It consists of sets of ideas about the past and forms of commemoration. Among researchers, the relationship between memory and history can be divided into three groups. The first of them sees memory and history as the opposites. Memory is individual, subjective, emotional, difficult to verify. History, on the other hand, is collective, objective, and verifiable by sources. According to sociologist Barbara Szacka, history is an academic and scientific discipline, and memory is a collection of images of the past held by the members of a given community, including a number of cultural products created within the group and serving to be remembered (Szacka, 2006).

The second group, represented by Jacques Le Goff, among others, thinks that memory and history are in a relationship. The famous medievalist in his book Memory and history showed the development of collective memory from oral transmission to electronic memory. According to Le Goff, before a magazine was written, oral communication served to preserve collective memory and thereby strengthen its identity based on myths (myth of the beginning, family prestige seen in genealogies), but also on practical knowledge (Le Goff, 2007). Therefore, memory was an essential element of collective identity, concluded the French historian. According to Le Goff, the history after World War II is the history of ordinary man. The new history does not responds to the needs of nations and is not a teacher of life, but becomes part of the search for identity (Le Goff, 2007). "History is a kingdom of inaccuracies and imperfections", Le Goff argued. This is because history is not an exact science, it arises in dialogue, and does not restore, but reconstructs life (Le Goff, 2007).

The historian can also be included in the third group. For this group, historical memory is a kind of instrument of liberation from historiography, which is a form of imposing the image of the past. We also include here: Dawid Lowenthal - "memory does not preserve the past, but 
adapts it to current conditions" (Lowenthal, 1985), Benedetto Croce - "every story is a history of the present" (quoted after: Le Goff, 2007), Marc Bloch - we understand the present through the past, and Hayden White - historiography is a literary work in which events are told and explained by the author. History seems to argue that a member of this group is a process of building it, which says more about today than yesterday.

\section{Cultural memory and dialogical memory}

The main theoreticians of cultural memory are the Germans: Aleida and Jan Assmann, and the French: Maurice Halbwachs and Pierre Nora. Sociologist Maurice Halbwachs wrote that memory develops along with the process of socialization (Halbwachs, 1969). Collective memory arises as a result of the interaction between individual feelings and memories that come from the thinking of individual groups. Culture, as Jan Assmann wrote, creates connective structures and connects contemporary society to their ancestors throughout history, creating a "symbolic world of meanings" (area of experiences, expectations). Cultural memory is thus formulated by storing relevant experiences and memories of the past and including them in the consciousness of the generations living in the present. The sense of belonging to the community of cultural memory consists of the legal order (community of rules and values), and the narrative order (community of memory of the past) (Assmann, 2008). Communicative memory is a memory that man shares with his contemporaries. After the passing of witnesses to history, events from the past live as cultural memory in the consciousness of societies and at the same time as the subject of the historian's research. Certain points from the past, according to Assmann, are recorded and transformed into a sacred myth (Assmann, 2013). The cultural memory includes storage memory and functional memory. With the help of those instruments the community selects from among all the events of the past those most important for it: historical facts, museums, monuments or school textbooks (called products of functional memory culture) (Assmann, 2013). In the $20^{\text {th }}$ century, a new ethical dimension of memory appears in the context of the totalitarian victims. The order to remember ("One must not shirk the past", Assmann, 2013), to mourn and remember not only one's own victims, appeared in the writings of, among others, Hanna Arendt and Karl Jaspers.

According to Aleida Assmann, the culture of remembrance does not obscure the future by focusing on the past, but is an important element of transformation through responsibility and empathy. Assmann pointed out that the shared memory of victims and perpetrators gives better results for future relations between nations than shared forgetfulness. At the same time, she expressed concern for the asymmetry of memories in which, for example, for the Germans it were Jews, not Poles, who were victims of national socialism and World War II. A similar asymmetry in memory was noticed between Eastern and Western Europe when it came to commemorating the victims of Nazism or communism. She recognized the pursuit of Europeanization of national memories, i.e. their mutual complementation, with the goal and challenge of the present. According to Assmann, shared transnational memory should therefore have the character of a dialogic memory (Assmann, 2013). 


\section{Geschichtspolitik/Politics of memory}

This concept was supposedly introduced in 1986 by Christian Meier. The terms used as synonyms are "politics of memory" or "policy towards the past". The term "Geschichtspolitik" is usually critical, while the other two terms are regarded as positive or neutral. Geschichtspolitik is usually understood as an instrumental treatment of history for achieving political goals. It is consciously supporting the memory of specific events and characters. Four groups of tools are used to implement Geschichtspolitik: management of public space in the public and material dimension (monuments, holiday calendar), operation of memory institutions (archives, libraries, museums), education, upbringing, and science (central education standards, school coercion), justice (settling the past by identifying and punishing those responsible, e.g. for crimes against the Polish nation) (Ruchniewicz, 2016).

According to Anna Wolff-Powęska, there are 3 levels of remembering: individual, socio-communicative (individuals among themselves), cultural and institutional (institutions of private and public culture) (Wolff-Powęska, 2008). The mechanism of memory policy is also falsification of history or forgetfulness. Aleida Assmann also talked about 5 strategies of repression: consciousness or the compensation process (Hans Frank in the Nuremberg trial said that Germany suffered so much pain during the post-resettlement that it had long repented of their war crimes), externalization (the Nazis, not Germans were guilty), exclusion (deliberate repression of a specific experience) or distortion (in the family relationships Germany is more a victim than a perpetrator) (Assmann, 2009).

\section{Poland and Lithuania today}

The year 2018 was a special moment for Poland and Lithuania. Both countries celebrated the round anniversary of independence (Lithuania 16 February 1918, Poland 11 November 1918). However, the centenary of the independence of both countries was not celebrated in a completely carefree atmosphere. Lines Linkevičius, the Lithuanian Foreign Minister, in an interview with The Economist said: "We can never be relaxed" (quoted Charlemagne, 2018). He meant the threat from Russia, which on the one hand is an aggressor in Ukraine, and on the other has a powerful war arsenal in a neighbouring exclave in Kaliningrad. The country's security will be guaranteed by the membership in NATO and the presence of 1,200 Alliance soldiers in Lithuania, mainly the Germans. Opinion polls conducted at the request of the Ministry of Foreign Affairs in December 2017 indicated that for the inhabitants of Lithuania the main threat comes from Russia and Belarus (Opinion polls, 2018). Lithuanians expressed also their belief that foreign policy and diplomacy as well as close cooperation with the Baltic States and Poland contribute to their security. In 2015 Lithuania opened a terminal accepting liquefied gas to diversify its gas supplies. As a result, the country's imports from Russia cover only $30 \%$ of its annual demand for this raw material (previously it was 100\%). In connection with the outbreak of the conflict in Crimea, Lithuania also regularly increases its expenditure on armaments (from $0.88 \%$ of GDP in 2014 to $2 \%$ of GDP in 2018). In 2015 Lithuania also introduced a mandatory nine-month military service. 
The factor hindering the development of the country is the outflow of young educated people abroad and the aging of the society (Pew Research Center, 2017). In 2015330 thousand Lithuanians, or $10 \%$ of the country's population, lived in other EU countries. Lithuanian education, as many experts emphasized, needs to be reformed. The Lithuanian economy has not yet found its niche (it mainly exports machinery, textiles, and food) (FBI Factbook, Lithuania, 2020). Lithuania is usually associated with the Baltic Sea, amber, and basketball. Lithuania's main trading partners are Russia (15\% of imports and $13 \%$ of exports), Germany, Poland, and Latvia, who account for over $40 \%$ of exports and imports. The strategic Polish-Lithuanian partnership is based not only on the common neighbourhood, the sense of threat from Russia and membership in the European Union and the North Atlantic Pact. Both countries are involved in the construction of the road infrastructure, electronic network synchronization, and strengthening of NATO's defense potential in the region. Poland, like Lithuania, although of course on a different scale, has a demographic problem related to low population growth, aging of the population, and migration of its inhabitants (among EU countries, Poles are the largest national group with higher education who live outside Poland). Poland's economic results are constantly improving. However, when it comes to comparing GDP per capita, Poles are still in the tail of the EU countries. Poles, like Lithuanians, are looking for their export goods. Exporting fruit and vegetables, in particular apples, and being a subcontractor for the German car production is definitely not enough (FBI Factbook, Poland, 2020). The country is mainly associated with the figures of Pope John Paul II, Lech Wałęsa, and Robert Lewandowski. The Warsaw government's goal is also to achieve energy independence. Poland opened a LNG terminal in Świnoujście, which can accept liquefied gas supplies, and initiated the Baltic Pipe construction project to enable the import of this medium from Scandinavia (Darasz, 2019). Poland would like to play the role of a leader in Central and Eastern Europe. An attempt to coordinate Poland's position with that of the other countries of the region as part of the so-called Intermarium group allows for more effective submission of certain projects on the EU forum. The community of interests, values, and a similar view of history are also promoted in the contemporary Polish-Lithuanian relations. The expression of this is the joint celebration of the anniversaries related to the history of the Polish-Lithuanian Commonwealth (Linkevičius congratulates Poland on its Independence Day, 2018).

\section{Historical policy in Polish-Lithuanian relations}

In an interview with the Polish Radio, the head of the Lithuanian Parliament, Victor Prancketis, reminded that the Polish-Lithuanian Commonwealth of 1569-1795 (a joint Polish-Lithuanian state), was the first example of a good regional cooperation between two states, not only on the military, but also political and cultural levels. "This union was an example of cooperation for the English and Scots. It is also an example of cooperation for many contemporary formats" (Akińczo, 2019). These words express a fundamental change in the way we view the common Polish-Lithuanian past in the last three decades. This change is symbolized by joint celebrations of important anniversaries such as 1 July, the anniversary of the act of the Union of Lublin signing, 
and 3 May, the anniversary of the Constitution of 3 May 1791. A special historical celebration took place in Vilnius in November 2019. With the participation of delegations from Poland, Belarus, and Ukraine, the remains of the heroes who took part in the anti-Russian January Uprising in 1863-1864 were buried with honours. These celebrations mark a characteristic change that took place in the Lithuanian historical policy in relation to the assessment of the traditions of the common Polish-Lithuanian state. Admittedly, the President of Lithuania Valdas Adamkus during his visit to Poland in April 1998 said: "Lithuania and Poland retain the unique features of their historical and cultural heritage, at the same time being a kind of spiritual community, covering a large region of Central Europe" (Korzeniowska, 1999). However, the Polish-Lithuanian Good Neighbourhood Treaty of 1994, signed four years earlier, suggested that both nations should turn to the future and give up considering historical issues, leaving them to be historians.

The referral of cases to historians was primarily due to the difficult experience of relations between the two countries or a completely different interpretation of the shared history. Lithuanians expected Poles to recognize that in the years 1920-1939 they occupied Vilnius and officially apologize for that (Vilkauskaite, 2013). The causes and consequences of the Polish-Lithuanian cooperation, which took the form of a dual state, a bi-confederation, ruled by the common monarch, were assessed differently. In striving to manifest their separateness, Lithuanians exhibited the earlier events in their historiography: the pagan times, the period of the Grand Duchy of Lithuania in the Middle Ages, and the period of the Lithuanian Republic 1918-1940.

The Polish-Lithuanian Union has been considered the "shameful card" by the Lithuanian historiography for a long period of the last 30 years. The Polish historians look differently at the history of the Union. According to Poles, the initiative to conclude a union was to come from the Lithuanian prince Jogaila (Polish Jagiełło) and was accepted by queen Jadwiga of Poland, the magnates and the middle class of Lesser Poland. According to the Lithuanians, the project of cooperation was put forward by the Polish side (the Polish historian Grzegorz Błaszczyk, reconciling both positions, wrote about a combination of circumstances which led to the signing of the agreement). The answer to the question of who was the initiator of the cooperation is important from a Lithuanian perspective, because it enables to show that it was an idea imposed by Poles, and Lithuania wished to remain separate. However, the last word on the Polish-Lithuanian question belonged to Jogaila. As an alternative, the Grand Duke of Lithuania could marry the daughter of Moscow's prince Dmitry of the Don, Sophia (even a preliminary contract was signed which he eventually cancelled). According to the Polish historian Oskar Halecki, Jogaila preferred to be the Polish King than a Moscow's vassal (Rachuba, Kiaupene, Kiaupe, 2009). The Krewo Treaty of 1385 introduced Lithuania into Catholic Europe, strengthened its prince's power over the rest of the dynasty's members, and defended it against the Teutonic Knights, thereby increasing the prestige of the state, satisfying the ambition of the ruler, and fostering the economic development (Lithuanian and Lesser Poland townsmen sought to conclude the agreement). The disadvantages of the agreement from a Lithuanian perspective were: political subordination to Poland, resistance of the Ruthenian and Orthodox peoples, cultural differences, and stereotypes. For Poles, the Union was an event that ended the Polish-Lithuanian feud over the influences in Russia, created 
an alliance against a common enemy, i.e. the Teutonic Knights, laid the foundations for economic development and power, and justified the mission to Christianize the last pagan state in Europe. The Lithuanian historians emphasized that throughout the entire period of Polish-Lithuanian cooperation lasting four centuries, Grand Duchy of Lithuania strove to remain separate. Vytautas the Great, Jogaila's cousin and the facto Grand Duke of Lithuania, sought to obtain the crown just before his death. The transformation of a personal union into a new state, which initiated the creation of the Polish-Lithuanian Commonwealth in 1569, was, according to Lithuanians, the effect of a military threat from Moscow and the pressure on the last Jagiellonian dynasty member, Sigismundus Augustus, exerted mainly by the boyars, to incorporate part of the lands of the Grand Duchy of Lithuania into the Crown of the Polish Kingdom (Błachowska, 2009).

The Lithuanian historians emphasized reproachfully that the Polish-Lithuanian Commonwealth period is the time when Lithuania was perceived as part of Poland and a country embedded in the history of Poland (Eidintas, Bumblauskas, Kulakauskas, Tamosaitis, 2013). The Union of Lublin has established a common foreign policy, the general Parliament, and the equal rights of the Polish-Lithuanian nobility. The result was a complex identity expressed by the phrase gente Ruthenus, natione Polonus (of Russian origin, of Polish nationality). The Polish-Lithuanian identity was determined not by religion or nationality but by culture. At the end of the $18^{\text {th }}$ century, the term "Pole" referred to a citizen of the Polish-Lithuania Commonwealth, but by definition it did not mean a person who speaks Polish and is Catholic. The voluntary process of Polonization of the inhabitants of Grand Duchy of Lithuania was a response to the attractiveness of Polish culture (Snyder, 2006).

The Polish-Lithuanian state paved the way for establishing a unique system which was the nobility democracy and then the election monarchy. The reasons of the collapse of the state in 1795 , as seen by some Polish historians in the $19^{\text {th }}$ century, included, besides some consequences of the union, the wars in the East, which weakened the state. The first synthesis of the Lithuanian history was created by Teodor Narbutt in the first half of the $19^{\text {th }}$ century - The ancient history of the Lithuanian people. The roots of the Lithuanian state were traced back to the $11^{\text {th }}$ century, when the Lithuanian prince Kernus conquered Ruthenia Kryvitska on the upper Neris (Błachowska, 2009). The first political organisms, formed between the $11^{\text {th }}$ and $13^{\text {th }}$ centuries, were united after 1240 by Mindaugas. The creation of the Grand Duchy of Lithuania was to be the result of tolerance and diplomatic endeavours directed towards Ruthenians, who surrendered voluntarily to the Lithuanian power. Narbutt emphasized that Lithuanians were ready to open to Western Christianity from the times of Gediminas. The Union was concluded with Poland rather than with Russia because it gave Lithuanians freedom and liberty. Narbutt criticized Jogaila not for the existence of the Union but for the lack of strong hereditary power in both members of the Polish-Lithuanian state.

Emerging in the late $19^{\text {th }}$ and early $20^{\text {th }}$ century, Lithuanian nationalism rejected the Polish-Lithuanian Union of 1569, which was considered the surrender and killing of the Lithuanian culture and language. The Lithuanian intelligentsia began to build an ethnic autonomous Lithuania, reconstructing the Lithuanian language (using the Czech spelling to distinguish it from the Polish) 
and proclaiming that the inhabitants of Vilnius are not Poles but Poles of Lithuanian origin (Snyder, 2006). Poles referred to these aspirations as a Lithuanian fad, and regarded Lithuanian as a dialect of the inhabitants of the former Grand Duchy. The key moment for the Polish-Lithuanian relations in the $20^{\text {th }}$ century was the Lithuanians' rejection of the idea of renewing the state relationship between Poles and Lithuanians, suggested by the Polish leader Marshal Józef Piłsudski in 1919, as well as the territorial dispute over the Vilnius region. "The Poles formed a state trampling the interests of the nations with whom they shared the past, trying to impose their will on them", we could read in the opinions of the Lithuanian historians Jurate Kiaupene and Zigmantas Kiaupe. From a Lithuanian perspective, these big state ambitions, the demands of the Polish minority in Lithuania, and a distorted view of the history of the Grand Duchy of Lithuania was to be the cause of the Polish-Lithuanian tensions that resulted in the interwar dispute over Vilnius in the $20^{\text {th }}$ century (Rachuba, Kiaupene, Kiaupe, 2009). The September defeat of Poland in 1939 and the recovery of the Vilnius region by Lithuania, passed on to it by the USSR, was a short-term success. Today, among the Lithuanian politicians, we can hear voices that history teaches us not to enjoy the failures of others - in relation to the defeat of Poland. However, were it not for the Molotov-Ribbentrop Pact, Vilnius would not be with Lithuania, others argue.

\section{Think ahead, beyond the shadows of the past}

On the occasion of the adoption of the agreement between Poland and Lithuania in April 1994, President Lech Wałęsa said in the Lithuanian Parliament that "Poles and Lithuanians are nations entangled in history". An American historian Timothy Snyder wrote that Poles in negotiations before signing the Polish-Lithuanian Agreement kept European standards: they did not mix diplomacy with history, did not conduct discussions in the spirit of apologizing for the historical sins (Snyder, 2006). They stated they had no territorial claims against Lithuania and recognized Poles in the Vilnius region as the Lithuanian citizens, but demanded respect for their cultural rights. At the same time, they did not apologize for the period of 1920-1939 when Vilnius's was part of Poland.

Poles, in their Eastern policy after 1989, decided to move their Eastern neighbours to the West, which meant to politically and permanently bring them out of Russia's influence. This policy expressed appreciation for the concept created in the 1970s in the circles of the periodical Kultura edited by Jerzy Giedroyc and Juliusz Mieroszewski. It assumed that the sovereignty of Poland, Belarus or Ukraine was a factor favouring Poland's independence, while the subordination of these countries to Russia threatened also with enslaving Poland.

A permanent element of the Polish-Lithuanian differences in the last quarter century is the issue of the status of the Polish minority in Lithuania (Żurawski vel Grajewski, 2016). There are 200,000 Poles living in Lithuania, representing nearly 7\% of the country's population (according to the 2001 census, 234989 people declared Polish nationality). The minority is concentrated in Vilnius (around 100,000, 20\%) as well as in the Vilnius (60\%) and Šalčininkai (80\%) regions. The rights of Poles in Lithuania are violated on several issues: spelling of names in official documents in accordance with the Polish spelling and grammar, the presence of the Polish language in the 
public space (e.g. street names in two languages), availability and functioning of education in Polish. The problem is also the return of the property, taken away in Soviet times, to a Polish organization and manipulation of the boundaries of constituencies with the intention of breaking up the Polish votes (Nowak, 2017).

The history of relations between the Polish minority and the authorities in Vilnius had also difficult times. The Polish national minority in Lithuania behaved in a disloyal manner when the independent Lithuania was declared. During the vote on independence in the Supreme Council of Lithuania on 11 March 1990, Lithuanian Poles were the only group that refused to support this resolution and abstained. Poles boycotted the independence referendum of February 1991 (only 15\% supported the idea of Lithuania's independence) (Źurawski vel Grajewski, 2016). A year earlier, the Polish National Territory was proclaimed in Eišiškès (Polish Ejszyszki) based on the constitutions of the USSR. The demand for autonomy, of which the exponents were the Polish communists, did not gain support of the Polish government, and the Lithuanian authorities in response dissolved the councils of the Šalčininkai and Vilnius regions. The hostile attitude of Poles was explained by the experience of difficult relations with Lithuanians under Soviet rule and susceptibility to Russian propaganda (20\% of those declaring Polish nationality speak Russian as their home language, and $8 \%$ Lithuanian language). According to the Lithuanian nationalists, strengthening the process of Lithuanization of young Poles is a measure against the influence of the Russian media. This is due to the fact that most Poles in Lithuania have better command of Russian than Lithuanian. Indeed, $60 \%$ of the population other than Lithuanian derives their knowledge from Russian-language media. However, Poles are not necessarily among them. This is because Poles have the best media in their own language: the daily "Kurier Wileński", the monthly "Magazyn Wileński", a private radio station "Radio znad Wilii", and the internet portal Wilnoteka. The members of the Polish minority in Lithuania differ in the assessment of their situation. As many as $44 \%$ of them believe their rights in Lithuania are respected while another $40 \%$ think they are not. $16 \%$ have no opinion. Only $14 \%$ of Poles feel discriminated (Fuksiewicz, 2013).

According to the Polish opinion polls from 2004 and 2015, Lithuanians were recognized as the third best neighbour of Poland after the Czech Republic and Slovakia (TNS OBOP, 2004; CBOS, 2015). Poles also point to Lithuania as one of those three countries that are not bad neighbours. Unfortunately, Poles have few associations with Lithuania (71\% have no associations). The conviction about the hostile attitude of Lithuanians towards Poland and Poles in Lithuania was expressed by $6 \%$ of respondents. Respondents spoke about the good and kind, as well as the unfriendly and selfish attitude of Lithuanians (approx. 2\%). The reason for such results is the lack of more intensive contacts between the nations. The sources of knowledge about each other are mainly information from history classes at school or from the media (Piwowar, 2007-2008). It is emphasized that the opinion polls reveal mainly the indifference in mutual relations. The process of weakening stereotypes is still in progress (Żołędziowski, 2003). The comparison also shows that Poles are more cosmopolitan, and Lithuanians more often express their national pride (90\%). 


\section{Conclusions}

The relationship between history and memory is disputable among researchers. Some talk about the boundaries separating historical facts from representation of the past. Others point to the reconstructive nature of the way the past is seen and made dependent on the perspective of the present. In the opinion of this author, historical memory is definitely reconstructive and is a response to the needs of the modern generation. We divide cultural memory, the concept invented as a result of the interaction between history and memory, into archiving and functional.

Geschichtspolitik/Politics of memory is the process of transferring events and persons from the archive to the functional level of cultural memory. Regardless of what tools are used for this and whether they are implemented individually or collectively, they serve to consolidate a certain image of the past.

The concept of dialogical memory is the postulate introduced by the German memoryologist Aleide Assman in order to transform historical policy by giving it a moral and democratizing dimension for building correct relations in the future. The postulate of building a transnational memory based on responsibility and empathy can be traced out in the case of changes in Polish-Lithuanian historical policy.

Poles and Lithuanians as nations in the present understanding of the word were shaped at the turn of the $20^{\text {th }}$ century. Both nations refer to the traditions of the Polish-Lithuanian Commonwealth as a multinational and multicultural state. The Poles made in 1918-1921 unsuccessful, due to the negative attitude of Lithuanians, attempts to restore the common state. Border disputes, however, led to a territorial dispute over the Vilnius region in 1920-1939.

At the end of the Cold War, Poland gave up its aspirations for the Vilnius region, while expecting full respect for the rights of Poles living there (Adamowicz, 2020).

Membership in the European Union and NATO are platforms joining Poles and Lithuanians in the $21^{\text {st }}$ century. They provide opportunities for cooperation and development of common interests and values. Common neighbourhood with the Russian exclave in Kaliningrad and a sense of threat from Russia enhances the mutual Polish-Lithuanian understanding. In both countries there is a perception that neither political party has achieved great success in relations with Russia during the last three decades (Jakniūnaite, 2015). Similar attitudes towards Russia can be seen in the internal Polish and Lithuanian discourses. One group insists on pragmatic business relationships and the avoidance of fruitless confrontational policies, especially on historical issues. The second perceive Russia as a threat to security, but does not suggest nervous movements due to the asymmetry of relations with the largest country in the world. Since the events of 2014 in Ukraine, in Poland and Lithuania a belief prevails that there is a strong threat from Russia.

One factor building the Polish-Lithuanian partnership is also historical dialogue. On the one hand, the Polish-Lithuanian discourse regarding the common past indicates a continuous process of reconstruction of historical memory, while on the other hand, the dialogical nature of contemporary relations between nations arose from the cultural conditions of modernity.

Lithuanian-Polish dialogical memory shows typical features of this phenomenon. They include: a democratic, multi-voice nature of bilateral debate, emancipation and articulation of such 
emotions as feelings of harm, loss or injustice; voting for the victim; internationalization process; and the joint anniversary celebrations.

Joint historical dialogue presented in the Lithuanian-Polish publications, the work of textbook committees constituted and still constitute the basis for approaching positions which can serve as the foundation of dialogical memory. This dialogue gave rise to the evolution of the rendition of mutual history in the school textbooks towards a more balanced image of the Polish-Lithuanian Commonwealth. The glorious moments from the common history seem to be more connecting than dividing Poles and Lithuanians (Kazlauskaitè, 2018; Srebrakowski, 2016; Jackiewicz, 2016).

The collapse of the USSR, which initiated a shift towards the West in both countries, made possible the expression of opinions on half a century of communist rule. An important integrating value for Poles and Lithuanians is the joint experience of historical injustice, which was the Yalta conference, as a result of which both nations came under the communist rule for half a century. Commemoration of the Stalinist victims is an opportunity to show the democratization of the historical narrative by giving voice to the witnesses of history, a phenomenon typical of all contemporary narratives of victims (Gortat, 2015). A common position on the joint historical past is expressed by the celebration of anniversaries related to the history of the common Polish-Lithuanian state: Union of Lublin, Constitution of 3 May 1791, or the national uprisings. Finally, the process of internationalization is commemorating the victims of the Nazi and Communist totalitarianisms in Central and Eastern Europe on the occasion of the anniversary of the signing of the Molotov-Ribbentrop Treaty on 23 August 1939 (Troebst, 2012).

\section{References}

Adamowicz, H. (2020). Linas Linkevičius o stosunkach polsko-litewskich. Kurier Wileński, 6 stycznia. Retrieved from: https://kurierwilenski.lt/2020/01/06/linas-linkevicius-o-stosunkach-polsko-litewskich/ (12.02.2020).

Akińczo, A. (2019). Viktoras Pranckietis: Zadanie Litwy i Polski-utrzymać obecne stosunki. Retrieved from: https:// dzieje.pl/aktualnosci/viktoras-pranckietis-zadanie-litwy-i-polski-utrzymac-obecne-stosunki (12.07.2019).

Assmann, A. (2009). Pięć strategii wypierania ze świadomości. In: M. Saryusz-Wolska (ed.), Pamięć zbiorowa i kulturowa. Współczesna perspektywa niemiecka (pp. 334-336). Kraków: Universitas.

Assmann, A. (2013). Między historia a pamięcią. Antologia. Warszawa: Wydawnictwo Uniwersytetu Warszawskiego.

Assmann, J. (2008). Pamięć kulturowa. Pismo, zapamiętywanie i polityczna tożsamość cywilizacji starożytnych. Warszawa: Wydawnictwo Uniwersytetu Warszawskiego.

Błachowska, K. (2009). Wiele historii jednego państwa. Obraz dziejów Wielkiego Księstwa Litewskiego do 1569 roku w ujęciu historyków polskich, rosyjskich, ukraińskich, litewskich i białoruskich w XIX wieku. Warszawa: Wydawnictwo Neriton.

Buraczewski, J. (2020). Mniejszość litewska obchodzi 30. rocznicę odzyskania niepodległości Litwy. Retrieved from: https:/www.dzieje.pl/aktualnosci/mniejszosc-litewska-obchodzi-30-rocznice-odzyskania-niepodleglosci-litwy (12.07.2019).

Charlemagne (2018). Lithuania hopes the next century is quieter than the last. The Economist, 15 lutego. Retrieved from: https://www.economist.com/europe/2018/02/15/lithuania-hopes-the-next-century-is-quieter-than-the-last/ (12.07.2019).

Darasz, J. (2019). Polish energy strategy assumptions to 2040. Retrieved from: https://www.obserwatorfinansowy.pl/ in-english/business/polish-energy-strategy-assumptions-to-2040/ (12.07.2019). 
Eidintas, A., Bumblauskas, A., Kulakauskas, A., Tamosaitis, M. (2013). History of Lithuania. Vilnius: Eugrimas Publishing House.

Fuksiewicz, A. (2013). W niewoli schematów. Nowa Europa Wschodnia, 5 (31), 45-50.

Gortat, J. (2015). Niemiecka polityka pamięci wobec ofiar wojny powietrznej. Łódź: Wydawnictwo Uniwersytetu Łódzkiego.

Halbwachs, M. (1969). Społeczne ramy pamięci. Transl. M. Król. Warszawa: PWN.

Jackiewicz, M. (2017). Recenzja podręcznika do historii dla klasy VII „Atrask istorija” (Odkryj historię). Retrieved from: https://men.gov.pl/zycie-szkoly/ksztalcenie-ogolne/komisje-podrecznikowe/polsko-litewska-dwustronnakomisja/materialy-z-posiedzenia-polsko-litewskiej-dwustronnej-komisji-ekspertow-do-badania-problemownauczania-historii-i-geografii-wroclaw-15-19-maja-2017/ (10.10.2019).

Jak Polacy postrzegaja swoich sqasiadów (2015). Warszawa, CBOS, 124/2015. Retrieved from: https://www.cbos.pl/ SPISKOM.POL/2015/K_124_15.PDF/ (10.10.2019).

Jakniūnaitè, D. (2015). A small state in the asymmetrical bilateral relations: Lithuania in Lithuanian-Russian relations since 2004. Baltic Journal of Political Science, 4, 70-93.

Kazlauskaite, R. (2018). Towards an embodied history: Metaphorical models in textbook knowledge of the controversial Polish-Lithuanian past. University of Helsinki. Retrieved from: https://www.academia.edu/36688273/ Towards_an_Embodied_History_Metaphorical_Models_in_Textbook_Knowledge_of_the_Controversial_Polish-Lithuanian_Past (10.10.2019).

Kennedy, P. (1994). Mocarstwa świata. Narodziny, rozkwit, upadek. Przemiany gospodarcze i konflikty zbrojne w latach 1500-2000. Warszawa: Książka i Wiedza.

Le Goff, J. (2007). Historia i pamięć. Transl. A. Gronowska, J. Stryjczyk. Warszawa: Wydawnictwo Uniwersytetu Warszawskiego.

Linkevičius congratulates Poland on its Independence Day (2015). Retrieved from: http://by.mfa.lt/default/en/news/ linkevicius-congratulates-poland-on-its-independence-day (10.10.2019).

Lowenthal, D. (1985). The past is foreign country. Cambridge: Cambridge Univeristy Press.

Nowak, W. (2017). Między Wschodem a Zachodem - geograficzne ukierunkowanie polityki polonijnej i jego przemiany w latach 1989-2017. Yearbook of the Institute of East-Central Europe, 15 (1), 139-158.

Nye, J.S. (2017). Soft power: The origins and political progress of a concept. Palgrave Communications, 3. Retrieved from: https://ssrn.com/abstract=2942713 or http://dx.doi.org/10.1057/palcomms.2017.8 (10.10.2019).

Nye, J.S. (1991). Bound to lea: The changing nature of American power. New York: Basic Books.

Nye, J.S. (2012). Przyszłość sity. Transl. B. Działoszyński. Warszawa: Wydawnictwo Naukowe PWN.

Pew Research Center (2017). Origins and destinations of European Union migrants within the EU. Retrieved from: https://www.pewresearch.org/global/interactives/origins-destinations-of-european-union-migrants-within-the$\mathrm{eu} /(10.10 .2019)$.

Piwowar, J. (2007-2008). O stereotypach Litwina w Polsce i Polaka na Litwie. Historia i Współczesność. Media - Kultura - Komunikacja Społeczna, 3-4, 201-208.

Prezydent Valdas Adamkus (1999). Przemówienie na Uniwersytecie Warszawskim 2 kwietnia 1998. In: K. Korzeniewska (ed. and trans1.), Pozostawione historii. Litwini o Polsce i Polakach (pp. 47-52). Kraków: Znak.

Przemówienie Prezydenta Lecha Wałęsy w Sejmie litewskim 26.04.1994 (2013). In: A. Srebrakowski (ed.), My nie bracia, my sąsiedzi. Polska perspektywa stosunków polsko-litewskich. Wrocław: Kolegium Europy Wschodniej.

Public opinion poll shows Lithuanians consider Poland as a key partner (2018). Retrieved from: https://usa.mfa.lt/ default/en/news/public-opinion-poll-shows-lithuanians-consider-poland-as-key-partner (10.10.2019).

Rachuba, A., Kiaupene, J., Kiaupe, Z. (2009). Historia Litwy. Dwugłos polsko-litewski. Warszawa: Wydawnictwo DIG.

Ruchniewicz, K. (2018). Polityka historyczna. In: J. Wojdoń (red.), Historia w przestrzeni publicznej (pp. 75-82). Warszawa: Wydawnictwo Naukowe PWN.

Sąsiedzi (2004). Omnimas. TNS OBOP, 078/04. Retrieved from: http://tnsglobal.pl/archiv_files/078-04.pdf(10.10.2019).

Snyder, T. (2006). Rekonstrukcja narodów. Polska, Ukraina, Litwa i Białoruś 1569-1999. Transl. Magda Pietrzak-Merta. Sejny: Pogranicze.

Srebrakowski, A. (2017). Recenzja podręcznika: 1. I. Kapleris, A. Meištas, K. Mickevičius, A. Laužikienè, Ž. Tamkutonytė-Mikailienè, Laikas. Istorijos vadovélis 10 klasei. I dalis, Vilnius 2016, Briedis Publishers, pp. 160, ilustracje, mapy, 
diagramy. 1a.) I. Kapleris, A. Meištas, K. Mickevičius, A. Laužikienė, Ž. Tamkutonytė-Mikailienė, Laikas. Istorijos vadovélis 10 klasei. II dalis, Vilnius 2016, pp. 203, ilustracje, mapy, diagramy e-szkoly. Retrieved from: https://men.gov.pl/zycie-szkoly/ksztalcenie-ogolne/komisje-podrecznikowe/polsko-litewska-dwustronna-komisja/materialy-z-posiedzenia-polsko-litewskiej-dwustronnej-komisji-ekspertow-do-badania-problemownauczania-historii-i-geografii-wroclaw-15-19-maja-2017 (10.10.2019).

Stobiecki, R. (2018). Pamięć historyczna. In: J. Wojdoń (ed.), Historia w przestrzeni publicznej (pp. 29-38). Warszawa: Wydawnictwo Naukowe PWN.

Szacka, B. (2006). Czas, przeszły, pamięć i mit. Warszawa: Scholar.

Troebst, S. (2012). 23 August: The genesis of a Euro-Atlantic Day of Remembrance. Remembrance and Solidarity. Studies in $20^{\text {th }}$ Century European History, 1, 15-53. Retrieved from: https://enrs.eu/uploads/media/studies_1. pdf (10.10.2019).

Vilkauskaite, D.O. (2013). From empire to independence: The curious case of the Baltic States 1917-1922. Honors Scholar Theses, 325. Retrieved from: https://opencommons.uconn.edu/srhonors_theses/325 (10.10.2019).

Wolff-Powęska, A. (2005). Zwycięzcy i zwyciężeni. II wojna światowa w pamięci zbiorowej narodów. Przegląd Zachodni, 2 (6), 4-40. 